\title{
Peningkatan Kemampuan Teknik Komunikasi pada Kader Kesehatan Ibu dan Anak di Banjardowo Semarang
}

\author{
${ }^{1}$ Ratnawati*, ${ }^{1}$ Muhammad Ulil Fuad, ${ }^{2}$ Muhammad Agus Supriyanto \\ ${ }^{1}$ Departemen IImu Keshatan Masyarakat, Universitas Islam Sultan Agung, Semarang, Indonesia \\ ${ }^{2}$ Departemen IImu Patologi Anatomi, Universitas Islam Sultan Agung, Semarang, Indonesia \\ ${ }^{*}$ Corresponding Author: \\ JI. Kaligawe Raya Km.4. Semarang, Jawa Tengah 50112; PO Box 1054/SM \\ E-mail: ratnawati@unissula.ac.id
}

$\begin{array}{cccc}\text { Received: } & \text { Revised: } & \text { Accepted: } & \text { Published: } \\ 15 \text { Desember 2021 } & \text { 19 Desember 2021 } & \text { 1 Januari } 2022 & 15 \text { Januari } 2022\end{array}$

\begin{abstract}
Abstrak
Status gizi dan kesehatan ibu dan anak sebagai penentu kualitas sumber daya manusia. Periode ibu hamil dan anak sampai 2 tahun merupakan golden periode dari seoarang anak. Tujuan pengabdian ini adalah meningkatkan pengetahuan dan kemampuan kader dalam melakukan pendampingan kesehatan kepada masyarakat. Metode pelaksanaan kegiatan dalam masa pandemi ini mengunakan HP android sebagai sarana dalam melakukan peningkatan skill kader. Materi yang disampaikan kepada kader dalam bentuk link YouTube video rekaman zoom, dan file PPT. Evaluasi peningkatan pengetahuan yang diharapkan bisa meningkatkan skill kader melalui pre-test sebelum melihat materi yang disampaikan dan posttest setelah melihat/ mendengar materi. Nilai pre-test dan post-test kader dianalisis dengan Paired t-test. Hasil analisis Paired t-test nilai pre-test dan post-test didapatkan $p=1$ yang berarti bahwa tidak ada perbedaan yang bermakna secara statistik antara nilai pre-test dan post-test setelah penyampaian materi.
\end{abstract}

Kata kunci: Kader kesehatan; komunikasi

\begin{abstract}
Nutritional status and health of mothers and children as a determinant of the quality of human resources. The period of pregnant women and children up to 2 years is the golden period of a child. The purpose of this service is to increase the knowledge and ability of cadres in providing health assistance to the community. The method of carrying out activities during this pandemic uses an Android phone as a means to improve cadres' skills. The material presented to the cadres are in the form of a YouTube link, video recording, zoom, and PPT file. Evaluation of the increase in knowledge that is expected to improve the skills of cadres through a pre-test before seeing the material presented and a post-test after seeing / hearing the material. The pre-test and post-test of cadres were analyzed by Paired T-test. The results of the Paired $T$ test analysis of the pre-test and post-test scores obtained $p=1$, which means that there is no statistically significant difference between the pre-test and post-test scores after the delivery of the material.
\end{abstract}

Keywords: Health cadres; communication 


\section{PENDAHULUAN}

Kelurahan Banjardowo terletak di Kecamatan Genuk Kota semarang yang merupakan daerah urban, terdiri dari $8 \mathrm{RW}$ dengan $43 \mathrm{RT}$ dengan jumlah penduduk dengan pekerjaan terbanyak sebagai buruh industri sebanyak 2.329 orang $(59,04 \%)$. Pendidikan masyarakat didominasi SD (23,27\%) dan SMP (22,01\%) (Kelurahan Banjardowo, 2019). Kelurahan Banjardowo memiliki RW IV yang dijadikan sebagai kampung KB. Pemerintah dalam memilih atau menentukan wilayah yang akan dijadikan lokasi Kampung KB harus mempunyai ada tiga kriteria Kriteria utama: yang mencakup dua hal, yaitu Jumlah Keluarga Pra Sejahtera dan KS 1 (miskin) di atas rata-rata Pra Sejahtera dan KS 1 tingkat desa/kelurahan di mana kampung tersebut berada, jumlah peserta KB di bawah rata-rata pencapaian peserta KB tingkat desa/kelurahan di mana kampung KB tersebut berlokasi. Kriteria wilayah yang mencakup 10 kategori wilayah (dipilih salah satu), yaitu Kumuh, Pesisir, Daerah Aliran Sungai (DAS), Bantaran Kereta Api, Kawasan Miskin (termasuk Miskin Perkotaan), Terpencil, Perbatasan, Kawasan Industri, Kawasan Wisata, dan Padat Penduduk. Selanjutnya dalam menentukan kriteria wilayah yang akan dijadikan sebagai lokasi pembentukan Kampung KB dapat dipilih satu atau lebih dari sepuluh criteria yang ada. Kriteria Khusus: yang mencakup 5 hal, yaitu: kriteria data di mana setiap RT/RW memiliki Data dan Peta Keluarga, kriteria kependudukan di mana angka partisipasi penduduk usia sekolah rendah, kriteria program KB di mana peserta KB Aktif dan Metode Kontrasepsi Jangka Panjang (MKJP) lebih rendah dari capaian rata-rata tingkat desa/kelurahan serta tingkat unmet need lebih tinggi dari rata-rata tingkat desa/kelurahan, kriteria program pembangunan keluarga di mana partisipasi keluarga dalam pembinaan ketahanan keluarga, pemberdayaan ekonomi dan partisipasi remaja dalam kegiatan GenRe melalui PIK-R masih rendah, kriteria program pembangunan sektor terkait yang mencakup setidaknya empat bidang, yakni kesehatan, ekonomi, pendidikan, pemukiman dan lingkungan, dan masih bisa ditambah dengan program lainnya sesuai dengan perkembangan(BKKBN, 2018). Berdasarkan kriteria tersebut dapat kita ketahui bahwa Kelurahan Banjardowo merupakan salah satu kelurahan dengan penduduk yang sebagian besar miskin dan cakupan KB-nya juga rendah. Posyandu merupakan salah satu bentuk Upaya Kesehatan Bersumber Daya Masyarakat (UKBM) yang dikelola dan diselenggarakan dari, oleh, untuk, dan bersama masyarakat dalam penyelenggaraan pembangunan kesehatan, guna memberdayakan masyarakat dan memberikan kemudahan kepada masyarakat dalam memperoleh pelayanan kesehatan dasar untuk mempercepat penurunan angka kematian ibu, bayi, dan balita(Kemenkes RI, 2014)

Kader adalah seorang tenaga sukarela yang direkrut dari, oleh dan untuk masyarakat, yang bertugas membantu kelancaran pelayanan kesehatan. Keberadaan kader sering dikaitkan dengan pelayanan rutin di posyandu. Sehingga seorang kader posyandu harus mau bekerja secara sukarela dan ikhlas, mau dan sanggup melaksanakan kegiatan Posyandu, serta mau dan sanggup menggerakkan masyarakat untuk melaksanakan dan mengikuti kegiatan Posyandu. Menurut Direktorat Bina Peran Serta Masyarakat Depkes RI kader merupakan warga masyarakat setempat yang dipilih dan ditinjau oleh masyarakat dan dapat bekerja secara sukarela". Kader kesehatan bisa laki-laki atau wanita yang dipilih oleh masyarakat dan dilatih untuk menangani masalah-masalah kesehatan perseorangan maupun masyarakat, serta bekerja di tempat yang dekat dengan pemberian pelayanan kesehatan. Kader disebut juga sebagai penggerak atau promotor kesehatan. Kader sebagai penggerak kesehatan di masyarakat sebagai penghubung antara tenaga kesehatan dan masyarakat sangat membutuhkan kompetensi komunikasi. Berdasarkan hasil 
assessment dari kuesioner google form tentang kebutuhan materi teknik komunikasi dalam promosi kesehatan dan selama menjadi kader belum mendapatkan materi. Sebanyak 12 dari 16 kader yang mengisi google form menyatakan belum mendapatkan materi teknik komunikasi dan sebanyak $100 \%$ selama menjadi kader belum pernah mendapatkan materi ini. Berdasarkan latar belakang ini maka kami lakukan pengabdian dengan tema Teknik komunikasi.

\section{METODE}

Pengabdian ini dilakukan di Kelurahan banjardowo yang merupakan mitra dari Fakultas Kedokteran Universitas Islam Sultan Agung. Pengabdian dilakukan di Era Pandemi sehingga bentuk kegiatan membutuhkan modifikasi yang bisa diterima oleh kader dengan tetap sesuai kebijakan pemerintah yang sedang memberlakukan Pembatasan Kegiatan Masyarakat (PKM). Penyampaian materi yang paling praktis di era pandemic adalah dengan cara zoom. Penggunaan zoom bagi masyarakat yang tidak bekerja dikantor merupakan hal yang berat terkait kuota dan belum familiar. Sasaran pengabdian ini adalah kader yang ada di Kelurahan Banjardowo sebanyak 27 orang. Pengabdian ini dilakukan dengan 4 tahap. Tahap pertama dilakukan assasment kebutuhan materi teknik komunikasi melalui goggle form, kemudian tahap ke dua mengisi pretest melalui google form, tahap ketiga menonton video YouTube rekaman zoom dan melihat PPT dan tahap keempat mengisi google form post-test. Metode tahapanpengabdian dapat dilihat pada diagram 1 dibawah ini.

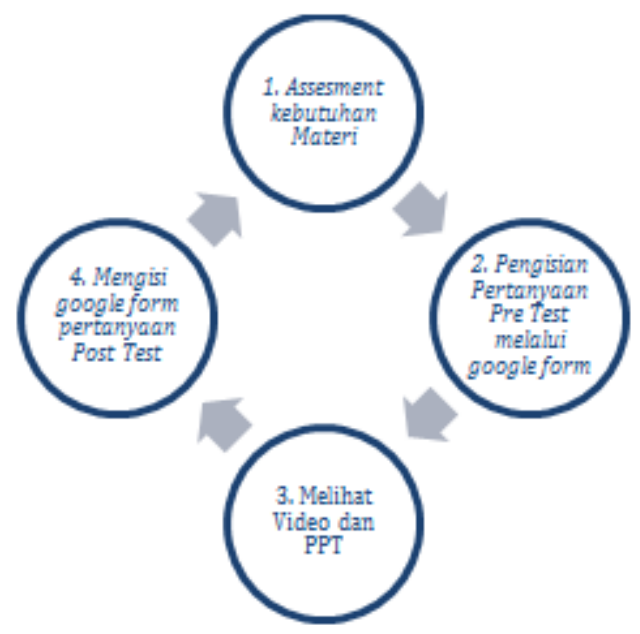

Gambar 1. Diagram tahapan pelaksanaan pengabdian

Tahapan assessment kebutuhan materi peningkatan pengetahuan dan ketrampilan kader tentang komunikasi adalah penting. Komunikasi adalah kemampuan utama yang harus dikuasai oleh kader karena kader merupakan kepanjangan tangan dari tenaga kesehatan (Puskesmas). Berdasarkan hasil penelitian yang dilakukan oleh simanjuntak, sebagian besar kader menyatakan pernah mengikuti pelatihan yang terkait dengan posyandu. Jenis pelatihan yang pernah diikuti oleh kader adalah pelatihan gizi, KB, imunisasi, kesehatan lingkungan, PIN, keorganisasian, kesehatan, lansia, dan PHBS. Kader juga menyatakan bahwa merekan mendapatkan manfaat dari pelatihan tersebut (Simanjuntak, 2012). Lindner dan Dooley dalam simanjuntak menyatakan bahwa kinerja yang efektif membutuhkan pengetahuan dan membantu membuat kemungkinan akuisisi pengetahuan baru, dimana pengetahuan ini dapat diperoleh melalui pelatihan-pelatihan (Simanjuntak, 2012). 
Di bawah ini merupakan video materi pelatihan dengan dua narasumber yang diberikan kepada ketua Forum FKK untuk dishare digrup kader dalam bentuk link YouTube tertutup yang hanya bisa dilihat oleh orang yang mendapatkan link ini. Materi pertama tentang Peningkatan Kemampuan Kader Kesehatan Posyandu (https://www.youtube.com/watch?v=U_FMRG81daQ). Materi yang kedua dengan Topik Teknik Komunikasi dan Pembuatan Media Promosi Kesehatan (https://youtu.be/ra2-euC_Wj8).

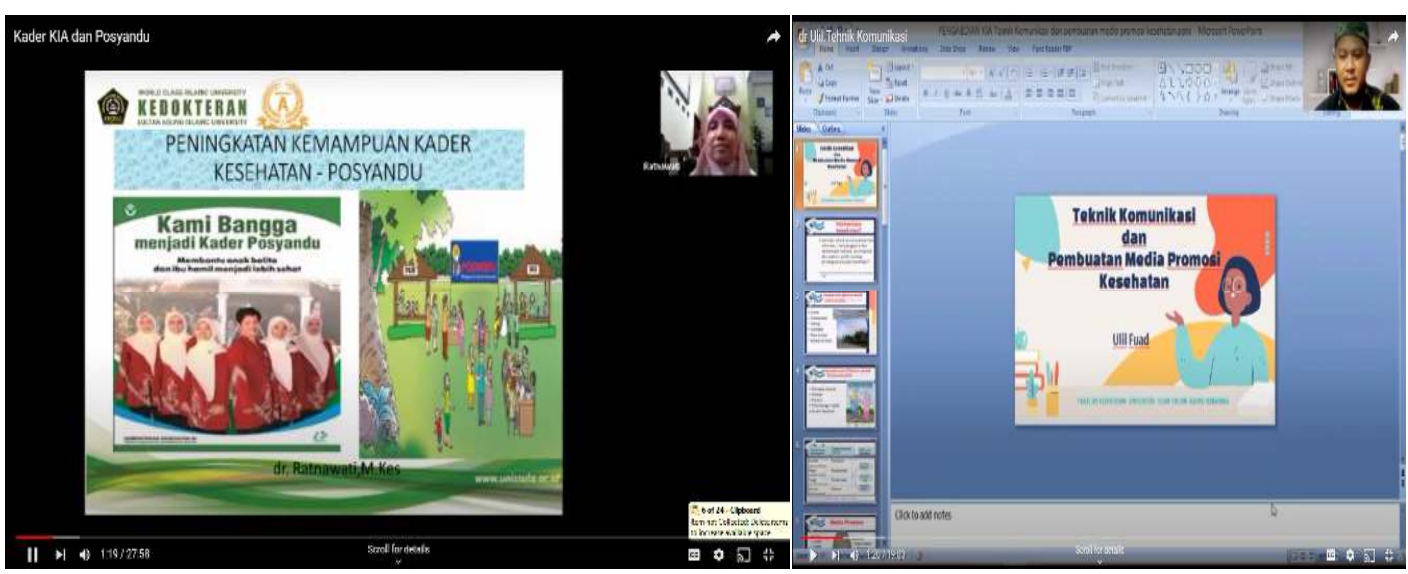

Gambar 2. Gambar halaman pertama presentasi melalui rekaman zoom dengan link akses YouTube.

\section{HASIL DAN PEMBAHASAN}

Jumlah kader yang ikut berpartisipasi dalam kegiatan pengabdian ini adalah pada tahap 1 hanya 16 kader $(59,2 \%)$, tahap 2 sampai 4 hanya 14 kader $(51,9 \%)$. Berdasarkan hasil assessment pada tahap pertama terkait teknik komunikasi dan media promosi kesehatan semua kader belum pernah mendapatkan materi ini selama menjadi kader, sebanyak 25\% kader menyatakan memperoleh materi teknik komunikasi dan media promosi kesehatan ini ketika sekolah. Kader menyatakan materi komunikasi penting sebanyak $87,5 \%$ dan $12,5 \%$ menyatakan sangat penting dan $100 \%$ menyatakan ingin mendapatkan materi ini. Hasil jawaban pertanyaan pre-test dan post-test responden dapat dilihat pada tabel 1 dibawah ini.

Tabel 1. Karakteristik Demografi dan Hasil Pre-test dan Post-test Kader

\begin{tabular}{|c|c|c|c|c|c|c|}
\hline Responden & Usia & Pendidikan & $\begin{array}{l}\text { Lama } \\
\text { Menjadi } \\
\text { Kader }\end{array}$ & Pre-test & Post-test & $\mathbf{P}^{*}$ \\
\hline Kader 1 & 57 & SMA & 26 & 70 & 100 & \\
\hline Kader 2 & 45 & SMA & 5 & 90 & 80 & 1 \\
\hline Kader 3 & 52 & SMP & 10 & 80 & 60 & \\
\hline Kader 4 & 45 & SD & 3 & 90 & 90 & \\
\hline Kader 5 & 41 & SMP & 1 & 70 & 70 & \\
\hline Kader 6 & 43 & SD & 5 & 70 & 70 & \\
\hline Kader 7 & 36 & SMA & 9 & 70 & 70 & \\
\hline Kader 8 & 45 & SMP & 15 & 70 & 70 & \\
\hline Kader 9 & 41 & SMA & 5 & 70 & 70 & \\
\hline
\end{tabular}




\begin{tabular}{rrrrrr}
\hline Kader 10 & 53 & SMA & 15 & 90 & 90 \\
\hline Kader 11 & 37 & SMA & 8 & 90 & 80 \\
\hline Kader 12 & 34 & SMA & 1 & 70 & 80 \\
\hline Kader 13 & 34 & SMA & 3 & 70 & 80 \\
\hline Kader 14 & 45 & SMA & 15 & 90 & 90 \\
\hline
\end{tabular}

\section{- Paired t-test}

Berdasarkan profil dari kader Posyandu di Kelurahan Banjardowo ini usia dalam rentang 34-57 Tahun dengan rerata usia 43,42. Semua usia kader terkategori usia produktif. Menurut Havigurst dan Robert dalam Simanjutak bahwa usia kader adalah termasuk usia dewasa madya (Pertengahan antara 30-60tahun) yang bisa melakukan pengembangan diri denan mengisi waktu senggang untuk kegiatan berorientasi pada keluarga dengan adanya perubahan minat dan tanggungjawab warga Negara dan sosial(Simanjuntak, 2012). Berdasarkan hasil penelitian di wilayah kerja Puskesmas Klangenan Kabupaten Cirebon ada hubungan yang signifikan antara umur dengan keaktifan kader dalam pengelolaan posyandu ( $p$ value lebih kecil dari $\alpha(0,002<0,05)$. Hal ini menunjukkan bahwa semakin matang umur responden maka akan berdampak pada perilaku kehadiran dalam pengelolaan posyandu. Responden yang berumur muda sebagian besar tidak aktif dalam mengelola posyandu sebanyak $(66,7 \%)$, hal ini disebabkan karena aktifitas pribadi masih tinggi dan sebagian besar memiliki. Kader yang berumur tua sebagian besar aktif ikut serta dalam mengelola posyandu sebanyak $(79,2 \%)$. Hal ini dikarenakan aktifitas pekerjaan rumah lebih sedikit(Banowati, 2018). Lama menjadi kader yang paling lama adalah 26 Tahun tetapi ada yang masih baru satu tahun menjadi kader. Hasil penelitian Banowati menunjukkan bahwa terdapat hubungan yang signifikan antara lama menjadi kader dengan kehadiran dalam pengelolaan posyandu ( $p$ value $=0,003$ ) (Banowati, 2018).

Rata-rata pendidikan kader adalah SMA sebanyak 64\%, masih ada 2 kader (14\%) yang berpendidikan SD, hal ini belum sesuai dengan persyaratan minimal kader adalah SMP. Pendidikan kader di Banjardowo jauh lebih baik jika dibandingkan dengan kader yang di Desa Bahung Sibatu-batu Kecamatan Sei Dadap Kabupaten Asahan, berdasarkan hasil penelitian disini menunjukan bahwa pendidikan kader terbanyak adalah SD dengan persentase 46,4\% (Gurning, 2016). Pendidikan berhubungan dengan dengan tingkat aktifitas kader, berdasrkan hasil penelitian di Kecamatan Soreang Kabupaten bandung didapatkan hasil tingkat pendidikan, dan lama menjadi kader berhubungan dengan tingkat aktivitas kader $p>0,05$ (Sukandar, Faiqoh and Effendi, 2018).

Dari Hasil analisis paired $T$ Test didapatkan hasil $p=1$, yang berarti tidak ada perbedaan pengetahuan kader antara sebelum dan sesudah terpapar materi video dan PPT. Hal ini bisa disebabkan kwantitas paparan materi tiap kader berbeda dan tingkat endidikan juga kurang homogen. Gambaran dari paparan yang diterima tiap kader bisa dilihat pada Tabel 2.

Tabel 2. Gambaran Kwantitas Paparan Materi Kader

\begin{tabular}{ccccc}
\hline Responden & Kwantitas Paparan Materi & $\begin{array}{c}\text { Media yang } \\
\text { disukai }\end{array}$ & $\begin{array}{c}\text { Media yang dipilih } \\
\text { selama Pandemi }\end{array}$ \\
\hline & Video & PPT & & \\
\hline Kader 1 & lengkap & Lengkap & PPT & Video \\
\hline Kader 2 & lengkap & lengkap & Video & Video \\
\hline
\end{tabular}


Jurnal ABDIMAS-KU: Jurnal Pengabdian Masyarakat Kedokteran

Volume 01, No. 01, Januari 2022

http://jurnal.unissula.ac.id/index.php/abdimasku

DOI: http://dx.doi.org/10.30659/abdimasku.1.1.9-16

\begin{tabular}{ccccc}
\hline Kader 3 & lengkap & Sebagian & Video & Video \\
\hline Kader 4 & lengkap & Lengkap & Video & Video \\
\hline Kader 5 & lengkap & Belum & Video & Video \\
\hline Kader 6 & lengkap & Sebagian & Video & Video \\
\hline Kader 7 & lengkap & Sebagian & Video & Video \\
\hline Kader 8 & lengkap & Sebagian & PPT & PPT \\
\hline Kader 9 & lengkap & Sedikit & Video & Video \\
\hline Kader 10 & sebagian & Sebagian & PPT & Zoom \\
\hline Kader 11 & belum & Belum & Video & Zoom \\
\hline Kader 12 & lengkap & Sebagian & PPT & PPT \\
\hline Kader 13 & lengkap & lengkap & Video & Video \\
\hline Kader 14 & lengkap & Sebagian & Video & Video \\
\hline
\end{tabular}

Peningkatan pengetahuan dan kemampuan skill kader merupakan salah satu strategi dalam meningkatkan derajat kesehatan di masyarakat, karena kader sebagai kepanjangan tangan dari tenaga kesehatan dan sebagai ujung tombak. Berdasarkan hasil penelitian yang dilakukan oleh Gurning menunjukkan terdapat 7 responden yang mempunyai pengetahuan kurang, semuanya kurang aktif dan tidak ada yang aktif. 14 responden yang mempunyai pengetahuan sedang, yang kurang aktif sebanyak 11 orang $(39,3 \%)$ dan hanya 3 orang $(10,7 \%)$ yang aktif. Terdapat 7 responden yang mempunyai pengetahuan baik, semuanya aktif dan tidak ada yang kurang aktif(Gurning, 2016). Hasil penelitian yang berbeda ditunjukkan oleh penelitian Banowati tidak ada hubungan yang signifikan antara tingkat pendidikan dengan kehadiran dalam pengelolaan posyandu di wilayah kerja Puskesmas Klangenan Kabupaten Cirebon Tahun 2018 ( $p$ value lebih kecil dari $\alpha(0,424>0,05)$. Hal ini menunjukkan bahwa kader kesehatan yang berpendidikan rendah maupun tinggi tidak berdampak pada kehadiran dalam pengelolaan posyandu (Banowati, 2018). Berdasarkan hasil google form yang diisi oleh kader dapat kita ketahui bahwa media yang paling disukai adalah video sebanyak $71,4 \%$. Materi yang diakses secara lengkap adalah video YouTube sebanyak $85 \%$. Peningkatan masyarakat dapat dilakukan melalui peningkatan pengetahuan maupun skill kepada kader. Hal ini sesuai dengan hasil penelitian yang dilakukan di Bengkulu, dimana pemberdayaan kader memberikan pengaruh terhadap pengetahuan ibu hamil terlihat bahwa terjadi peningkatan rata-rata skor pengetahuan ibu hamil tentang Program Perencanaan Persalinan dan Pencegahan Kehamilan (P4K). Sebelum pemberdayaan kader rata-rata skor pengetahuan ibu hamil 70,67 setelah dilakukan intervensi meningkat menjadi 92,50(Ningsih and Novira, 2020). Pada masa pandemi ini akses penerimaan paparan materi antara satu kader dengan kader yang lainnya tidak bisa diseragamkan karena paparan materi bersifat mandiri, tergantung individu tiap kader. Berbeda dengan ketika paparan materi dalam kegiatan dalam satu waktu dan tempat yang sama. Paparan materi di era pandemi ini yang paling mendekati bisa menyeragamkan adalah secara online dengan zoom meeting. Berdasarkan hasil isian google form hanya 14 persen yang mengingginkan zoom. Harapan dan keinginan yang disampaikan oleh kader terkait media penyuluhan ini merupakan gambaran dari keinginan masyarakat. Penggunaan zoom sebagai media yang digunakan oleh kaum professional maupun akademisi belum mampu laksana dilakukan bagi masyarakat. Keinginan dan harapan kader ini tidak sesuai dengan hasil penelitian yang dilakukan di Universitas ARS Bandung dengan hasil pembelajaran online menggunakan aplikasi google meet sudah efektif dan mahasiswa juga memberikan respon atau tanggapan yang sangat baik. Mahasiswa merasa pembelajaran dengan mengunakan zoom karena pembelajaran lebih fleksibel terkait penjadwalan., mahasiswa bisa mandiri dan bisa mendorong 
Mahasiswa untuk aktif dalam permbelajaran. Banyaknya fitur di dalam Zoom menjadikan pembelajaran lebih menarik. Selain itu, pemahaman dan penerimaan yang disampaikan oleh dosen dapat dirasakan oleh mahasiswa ARS(Junita Monica, 2021).

Pada pengabdian ini dapat kita ketahui bahwa keinginan membaca kader juga masih rendah, hanya $21 \%$ yang membaca PPT secara lengkap. Keinginan meningkatkan pengetahuan dan ketrampilan kader tidak terlepas dari motivasi kader. Motivasi dari kader dalam meningkatkan pengetahuan juga berpengaruh terhadap keinginannya untuk mengakses fasilitas yang bisa meningkatkan pengetahuananya. Hal ini tidak sesuai dengan hasil penelitian di Posyandu wilayah Puskesmas Selakau Kabupaten Sambas, terdapat korelasi antara pengetahuan dengan keaktifan kader dalam kegiatan posyandu ( $r=0,263 ; p=0,048)$ (Alhafij Azura, Erlisa Candrawati, 2017). Penelitian di Kecamatan Tondano Kabupaten Minahasa mendapatkan hasil bahwa terdapat perbedaan pengetahuan tentang ASI Esklusif yang bermakna pada kader antara sebelum diberikan pelatihan ASI eksklusif dengan sesudah pelatihan ASI eksklusif . Meningkatnya pengetahuan, dan keterampilan para kader posyandu tentang pemberian ASI eksklusif, dapat meningkatkan pemahaman dan kesadaran para ibu menyusui, sehingga pemberian ASI eksklusif dapat ditingkatkan(Malonda and Sanggelorang, 2020).

\section{KESIMPULAN}

Penyuluhan secara online belum bisa meningkatkan pengetahuan yang sama pada semua audien. Tingkat Pendidikan dan lama menjadi kader ikut berkontribusi terhadap motivasi dalam menningkatkan pengetahuan dan kemampuannya sebagai kader.

\section{UCAPAN TERIMA KASIH}

Penulis menyampaikan terima kasih kepada LPPM UNISSULA sebagai penyandang dana dan ketua Forum Kesehatan Kelurahan Banjardowo serta seluruh kader Banjardowo.

\section{DAFTAR PUSTAKA}

Alhafij Azura, Erlisa Candrawati, R. C. A. W. (2017) 'Motivasi Dan Pengetahuan Kader Meningkatkan Keaktifan Kader Dalam Kegiatan Posyandu', Nursing News, 2, pp. 556562. Available at: https://publikasi.unitri.ac.id/index.php/fikes/article/view/501/419.

Banowati, L. (2018) 'Hubungan Karakteristik Kader Dengan Kehadiran Dalam Pengelolaan Posyandu', Jurnal Kesehatan, 9(2), pp. 101-111. doi: 10.38165/jk.v9i2.85.

BKKBN (2018) Pembentukan Kelompok Kampung KB. Available at: https://kampungkb.bkkbn.go.id/kampung/2954/intervensi/45576/pembentukan-kelompokkampung-kb.

Gurning, F. P. (2016) 'Pengaruh Karakteristik Kader Terhadap Keaktifan Kader Posyandu di Desa Bahung Sibatu-Batu Kecamatan Sei Dadap Kabupaten Asahan', Jurnal JUMANTIK, 1(1), pp. 60-78. Available at: https://www.mikroskil.ac.id/ejurnal/index.php/jwem/article/view/68/57.

Junita Monica, D. F. (2021) 'Efektivitas Penggunaan Aplikasi Google Meet Sebagai Media Pembelajaran Online Pada Mahasiswa Saat Pandemi Covid-19', National Conference on Applied Business, Education, \& Technology (NCABET), 1(1), pp. 388-394. doi: 10.46306/ncabet.v1i1.32.

Kelurahan Banjardowo (2019) Data Kelurahan Banjardowo Semarang.pdf. Semarang. 
Kemenkes RI (2014) Kurikulum dan Modul Pelatihan K ader Posyandu.

Malonda, N. S. H., \& Sanggelorang, Y. (2020) 'Upaya Peningkatan Pengetahuan Kader Posyandu dalam Kegiatan Pelatihan Pendampingan Pemberian ASI Eksklusif di Kelurahan Tataaran II Tondano Selatan Kabupaten Minahasa', JPAl: Jurnal Perempuan dan Anak Indonesia, 2(1), p. 12. doi: 10.35801/jpai.2.1.2020.26830.

Ningsih, L., \& Novira, D. (2020) 'Upaya Peningkatan Pengetahuan dan Sikap Ibu Hamil dalam Program Perencanaan Persalinan dan Pencegahan Komplikasi (P4K) melalui Pemberdayaan Kader', Jurnal Kesehatan, 11(3), p. 386. doi: 10.26630/jk.v11i3.2239.

Simanjuntak, M. (2012) 'Karakteristik Sosial Demografi dan Faktor Pendorong Peningkatan Kinerja Kader Posyandu', Jurnal Wira Ekonomi Mikroskil, 2(1), pp. 49-58. doi: 10.25015/penyuluhan.v10i1.9914.

Sukandar, H., Faiqoh, R. \& Effendi, J. S. (2018) 'Hubungan Karakteristik terhadap Tingkat Aktivitas Kader Posyandu Kecamatan Soreang Kabupaten Bandung', Jurnal Sistem Kesehatan, 4(3), pp. 102-109. 